ArchiWa - Kancelarie - Zbiory

NR $4(6) / 2013$

Magdalena WiśNiewsKa

Uniwersytet Mikotaja Kopernika w Toruniu

\title{
ARCHIWUM JAKO MIEJSCE PAMIĘCI
}

Słowa kluczowe: miejsca pamięci; pamięć; archiwa społeczne; archiwa prywatne; samoświadectwa

Keywords: memorials, rememberance, social archive, private archive, testimonial

Abstract

W artykule autorka udowadnia, że archiwum jest miejscem pamięci, w zgodzie z rozumieniem tego terminu zaproponowanym przez Pierre'a Norę. Zgodnie z takim podejściem do tematu jest według autorki każde archiwum takim właśnie miejscem pamięci, bowiem jako instytucja przechowująca materiały archiwalne, pozwala ona w te materiały wejrzeć, a tym samym poznać przeszłość w nich zapisaną. Każdego rodzaju archiwum jak każde miejsce pamięci jest depozytariuszem przeszłości. Ponadto autorka stawia tezę, że archiwum to również miejsce kreowania pamięci. Autorka dzieli archiwa na dwie grupy, do pierwszej włączając archiwa państwowe, kościelne i bieżące, do drugiej natomiast - archiwa społeczne i prywatne. Jednocześnie wskazuje ona na dwie cechy, odróżniające archiwa z grupy drugiej od tych z grupy pierwszej, a są to DOBROWOLNOŚĆ (własna inicjatywa gromadzenia zasobu archiwalnego) i DOWOLNOŚĆ (głównie w doborze gromadzonych materiałów). Autorka zwraca uwagę na to, że archiwum prywatne służyć może kreowaniu siebie jako osoby lub kreowaniu pamięci rodu czy rodziny; jest samoświadectwem jego właściciela - to on bowiem nadaje mu pewien konkretny kształt, decydując tym samym, jaki kształt ma przyjąć w przyszłości pamięć o nim. Archiwa społeczne natomiast kreują pamięć o przeszłości np. danej zbiorowości czy danego terytorium, mogąc przy tym wpływać 
na kształt pamięci, a także w ogóle - czy zostanie ona zachowana. W przypadku archiwów społecznych autorka zwraca również uwagę na powody ich powstawania, przywołując zjawiska nazwane „przyśpieszeniem historii” oraz „demokratyzacją historii”.

Za prekursora badań nad tematem miejsc pamięci uznać należy francuskiego historyka Pierre’a Norę. W swej twórczości nigdy stuprocentowo i konkretnie nie zdefiniował on tego pojęcia, zresztą na przestrzeni lat rozumienie „miejsc pamięci” w dziełach Nory ewoluowało ${ }^{1}$. Najszersze ich postrzeganie proponuje chyba Pierre Nora w swym artykule pt. Between Memory and History: les lieux de mémoire z 1989 roku, gdzie „miejsca pamięci” to „wszelkie praktyki (przedmioty, organizacje), których podstawowym celem jest podtrzymywanie (stymulowanie) pamięci o przeszłości”2. Warto zwrócić uwagę na fakt, iż pomimo użycia słowa „miejsce”, które dość jednoznacznie kojarzy się z fizycznością, namacalnością, a nawet $\mathrm{z}$ topografią, miejsca pamięci nie muszą wcale mieć charakteru materialnego. Ich materialność schodzi na drugi plan, na pierwszy natomiast wysuwa się metaforyczne rozumienie „miejsca” - również jako znaku czy symbolu.

Nieco inne spojrzenie na miejsca pamięci proponuje Krzysztof Pomian w swym artykule opublikowanym na stronie internetowej Europejskiej Sieci Pamięć i Solidarność. Pisze on tam: „miejsca materialne i wyobrażone, gdzie wspomnienia zbiorowe występują w szczególnym stężeniu określa się mianem miejsc pamięci”3. Używanie jednak przeze mnie w tym miejscu takiej definicji wykluczałoby jako miejsca pamięci archiwa osobiste, zawierające materiały dotyczące jednej lub kilku tylko osób i kreujące pamięć jednostkową (lub pamięci jednostkowe) - bez związku właściwie ze wspomnianymi w definicji Pomiana wspomnieniami zbiorowymi i pamięcią zbiorową. Tym samym $\mathrm{w}$ artykule opisane zostaną archiwa będące miejscami pamięci w zgodzie z ich rozumieniem zaproponowanym przez Pierr'a Norę.

1 Syntetyczny obraz zmian rozumienia „miejsc pamięci” przez Pierre’a Norę daje w swej pracy Paul Ricoeur. Patrz: P. Ricoeur, Pamięć, historia, zapomnienie, przekł. J. Margański, Kraków 2007, s. 533-545.

2 A. Szpociński, Miejsca pamięci (lieux de mémoire), „Teksty Drugie” [„Second Texts"] 2008, nr 4, s. 13, za: P. Nora, Between Memory and History. Les lieux de mémoire, „Representation”, no. 26, Spring 1989.

3 K. Pomian, Pamięć podzielona: miejsca pamięci w Europie jako zjawisko polityczne i kulturowe, http://enrs.eu/images/teksty\%20pdf\%20pol/Pomian_pamiec.pdf, s. 2-3 (dostęp z dnia 5 V 2013 r.). 
Zgodnie z takim podejściem do tematu jest zasadniczo każde archiwum takim właśnie miejscem pamięci, bowiem jako instytucja przechowująca materiały archiwalne, pozwala ona w te materiały wejrzeć, a tym samym poznać przeszłość w nich zapisaną. Jak każde miejsce pamięci jest archiwum depozytariuszem przeszłości, bez względu na to, czy mówić będziemy o archiwach państwowych, tj. urzędach administracji państwowej i urzędach wiary publicznej, archiwach kościelnych czy nawet archiwach bieżących (nie musi przecież dany dokument mieć statusu materiału archiwalnego, czyli takiego, który ma być przechowywany wieczyście, aby mówić jego odbiorcy o przeszłości).

Spojrzenie na archiwa jako na instytucje (czy też może zjawiska), mające zaspokajać potrzebę pamięci, zostało już zaprezentowane w polskiej literaturze archiwalnej m.in. przez Waldemara Chorążyczewskiego. W swym artykule z 2005 roku zwraca on uwagę na zjawisko kreowania pamięci poprzez archiwa, podobnie jak zostało to poczynione w tym artykule. Za Stanisławem Roszakiem cytuje on Aleidę Assmann, podkreślając tym samym, że archiwum to również miejsce „konstruowania przeszłości (określanej jako pamięć władzy). Cechą wyróżniającą zapis takiej pamięci [...] jest związek z utrwalającą ją osobą, grupą czy instytucją, a więc zarazem subiektywizm (selektywność) w wyborze elementów zapamiętanych i zapomnianych".

Ponadto okazuje się, że pojawienie się w historii archiwów polskich idei archiwizowania wieczystego łączy się z ideą kreowania pamięci. Wieki XVI i XVII to początek używania archiwum jako narzędzia budowania prestiżu rodu (poprzez oparcie go na dawności tego rodu) oraz rodzinnej tradycji. Działo się to dzięki zachowywaniu dokumentów, które nie miały już żadnego znaczenia praktycznego, a jedynie swą rangą i wiekiem dodawały rodowi splendoru. Wiek XVIII przyniósł w Polsce „usamodzielnienie się motywu pamięci jako przesłanki powstawania archiwów"5. Wtedy właśnie nastąpiło szersze zainteresowanie historią, przejawiające się m.in. w odkrywaniu spuścizn przodków. W wieku XVIII miało również miejsce zjawisko tworzenia archiwów rodowych od podstaw poprzez kwerendy w księgach sądowych, co - można przypuszczać - było formą zaspokajania potrzeby pamięci. Zaczęto postrzegać archiwa jako skarbnice pamięci narodowej i symbol trwałości

4 W. Chorążyczewski, Archiwa i pamięć. Z dziejów polskich archiwów, „Archiwa Kancelarie - Zbiory”, t. 1, Toruń 2005, s. 14.

5 Tamże, s. 20. 
państwa. Okres zaborów to nadanie archiwom prywatnym znaczenia substytutu archiwów publicznych, te bowiem nie były w dyspozycji narodu polskiego, ale państw zaborczych. Celem archiwów stało się również podnoszenie morale Polaków oraz kształtowanie ich świadomości - rodowej, lokalnej czy narodowej, podkreślenie ciągłości istnienia narodu polskiego wobec zerwania ciągłości istnienia państwa ${ }^{6}$.

W tym miejscu zajmę się przede wszystkim dwoma typami archiwów: archiwami prywatnymi oraz archiwami społecznymi. Zostaną one pokazane w opozycji do archiwów państwowych, kościelnych i bieżących. Co jednak je różni? We wszystkich przecież przechowuje się przedmioty mówiące o przeszłości, stymulujące pamięć o niej; wszystkie są miejscami pamięci. Uważam jednak, iż jest jedna kategoria, która w aspekcie rozpatrywania archiwów jako miejsc pamięci odróżnia od siebie te dwie grupy, a można ją opisać dwoma słowami: DOWOLNOŚĆ i DOBROWOLNOŚĆ.

Wszystkie trzy archiwa z pierwszej grupy (tj. państwowe, kościelne i bieżące) istnieją dlatego, że zostały powołane przepisami prawa. Co więcej: również to, jakie materiały gromadzą w swoim zasobie, jest w całości lub w dużej mierze narzucone im odgórnie. Archiwa państwowe gromadzą to, co na podstawie ustalonych wcześniej z danym archiwum przepisów kancelaryjnych lub w ogólnych przepisach w wykazie akt uzyskało w ramach kwalifikacji archiwalnej kategorię A, czyli właśnie materiały archiwalne, przeznaczone do wieczystego przechowania. Również instytucje, które objęte są nadzorem archiwalnym, wskazywane są przez organy nadrzędne - Naczelną Dyrekcję Archiwów Państwowych. Zdarza się jednak, że archiwa interesują się dokumentacją inną jeszcze niż ta, którą na mocy prawa mają obowiązek się zajmować. Przejmują bowiem czasem archiwa państwowe np. spuścizny lub archiwa organizacji społecznych, jest to jednak niewielka część ich zasobu.

Podobnie działają również archiwa bieżące i archiwa kościelne - one również funkcjonują w ramach przepisów, których same nie ustalają, jednocześnie nie zbierając prawie wcale (w wypadku archiwów kościelnych) lub wcale (w wypadku archiwów bieżących) nic ponad to, co nakładają na nie przepisy. Nie chciałabym się bardziej szczegółowo nad tym rozwodzić, gdyż, jak wspomniałam nieco wcześniej, wolałabym omówić działalność archiwów prywatnych i społecznych.

\footnotetext{
6 Tamże, s. 19-24.
} 
W archiwach prywatnych również znajdują się często rzeczy, których właściciel archiwum nie chce, ale musi przechowywać, w głównej mierze po to, aby na podstawie danego dokumentu być w stanie dowieść swoich praw (np. majątkowych) lub dlatego, że ma on przekonanie, że dany dokument będzie mu niezbędny w przyszłości. Mam tu na myśli m.in. odpisy aktów stanu cywilnego, wypisy z ksiąg wieczystych, umowy o pracę, zeznania podatkowe, karty gwarancyjne różnorakich sprzętów i dowody ich zakupu, dokumentacja techniczna domu czy samochodu.

W archiwach prywatnych jednak więcej miejsca niż w archiwach wymienianych wcześniej poświęca się na gromadzenie dokumentów, których właściwie nikt ani nic (jak np. ewidentna potrzeba użytkowa czy prawna) nie każe nam gromadzić. Najbardziej chyba powszechnym tego przykładem mogą być zdjęcia. Mimo że nie ma przecież przymusu ich gromadzenia, to trudno byłoby chyba znaleźć osobę, która nie ma w domu ani jednej fotografii. A gromadzi się je z różnych powodów. Po latach od wydarzenia, uchwyconego przez aparat, można wziąć w rękę fotografię i powrócić pamięcią do przedstawionych na niej chwil - to właśnie jaskrawy przykład tego, że takie domowe, prywatne archiwum jest miejscem pamięci. Można jednak dzięki fotografiom przenosić pamięć o przeszłości dalej w czasie, a także między osobami, bowiem nie musi fotografia tylko przypominać o przeszłości osobom pamiętającym dane wydarzenie; może zobrazować je innym, może także przenieść tę wiedzę między pokoleniami - tak, że mimo iż żaden uczestnik zdarzenia już nie żyje, to jednak pamięć o nim jest wciąż żywa wśród następnych generacji. Bardzo dobrze również spisują się fotografie w tworzeniu więzi międzypokoleniowej oraz przekazywaniu następnym generacjom cennych wartości - idei, wzorców zachowań, poglądów.

W archiwach prywatnych dostrzegam jeszcze jedną rzecz, zasługującą w tym miejscu na uwagę, choć można by rzec, że odnaleźć ją będzie można raczej w archiwach zorganizowanych przez osoby „świadome dokumentacyjnie". Chodzi mi tutaj o kreowanie siebie jako osoby lub kreowanie pamięci rodu czy rodziny ${ }^{7}$. Związane jest to ze świadomością, że dane archiwum trafi kiedyś do rąk spadkobierców jego właściciela czy nawet do jakiejś publicznej instytucji (archiwum państwowego czy uniwersyteckiego), jeśli mówilibyśmy o osobie wybitnej i już w trakcie życia świadomej swojej wybitności,

7 M. Vorbek-Lettow, Skarbnica pamięci: pamiętnik lekarza króla Wtadystawa IV, oprac. E. Galos i F. Mincer, pod red. nauk. W. Czaplińskiego, Wrocław 2006. 
np. świetnym badaczu (można to odnieść również do znanej, cenionej i zasłużonej rodziny czy też rodu). Owa autokreacja może przejawiać się w różny sposób, np. pisaniem pamiętników z myślą o tym, że ktoś je kiedyś przeczyta, usuwaniem dokumentów, których treść wydaje się właścicielowi archiwum nieodpowiednia, to jest stawiająca go w złym świetle oraz wręcz przeciwnie - kreowanie dokumentów, mających być w przyszłości świadectwem wybitności danej jednostki czy rodu (nie mówię tutaj koniecznie o fałszowaniu dokumentów, ale raczej o ich umyślnym wywoływaniu, prowokowaniu ich powstania lub ich gromadzeniu). Mamy wtedy do czynienia z przypadkiem, kiedy archiwum prywatne jest samoświadectwem jego właściciela - to on bowiem nadaje mu pewien konkretny kształt, decydując tym samym, jaki kształt ma przyjąć w przyszłości pamięć o nim.

Zanim zacznę bardziej szczegółowo mówić o archiwach społecznych jako miejscach pamięci, chciałabym przytoczyć definicję, dzięki czemu zrozumieją Państwo, czym jest dla mnie archiwum społeczne.

Archiwa społeczne to instytucje pamięci gromadzące źródła (najczęściej do wybranego tematu) niebędące wytworem ich dysponenta, który to dysponent jednocześnie nie jest jednostką o charakterze państwowym (nadzorowaną przez struktury państwowe), samorządowym (nadzorowaną przez samorząd), kościelnym (nadzorowanym przez struktury kościelne) bądź komercyjnym (której celem istnienia jest czerpanie zysków z gromadzenia dokumentacji, jak to jest w przypadku firm przechowalniczych). Archiwum społeczne może być zatem prowadzone przez jednostki trzeciego sektora (tj. fundacje i stowarzyszenia), jak również osoby fizyczne czy partie polityczne, a w teorii również przedsiębiorstwa prywatne.

Istotą archiwów społecznych są więc dwie cechy:

- niepaństwowość; oddolna (społeczna właśnie) inicjatywa,

- gromadzenie dokumentacji „obcej” - niebędącej wytworem danej instytucji czy osoby, a jedynie przez nią zebranej (co odróżnia archiwa społeczne od archiwów bieżących np. stowarzyszeń i fundacji czy archiwów prywatnych i rodzinnych).

Jedną z najbardziej charakterystycznych cech archiwów społecznych, zaznaczających jednocześnie ich odmienność od pozostałych typów archiwów, jest sposób gromadzenia zasobu. Podczas gdy archiwa skupione w sieci państwowej są zazwyczaj wyłącznie odbiorcą dokumentacji, przekazywanej im przez wyznaczone jednostki organizacyjne w wyniku selekcji archiwalnej (o czym już wspomniałam), archiwa społeczne pozyskują zasób aktywnie. 
Odbywać się to może dwutorowo. Po pierwsze, archiwa poszukują osób, które mogą posiadać jakiegoś rodzaju źródła do interesującego dane archiwum tematu. Może to się odbywać albo przez ogłaszanie akcji gromadzenia źródeł w lokalnej (lub szerszej) społeczności (np. zbieranie bibuły organizowane przez Centrum Dokumentacji Czynu Niepodległościowego ${ }^{8}$ ), albo poprzez docieranie do potencjalnych darczyńców dzięki informacjom uzyskanym od osób, które już nawiązały jakąś współpracę z danym archiwum. W pierwszym wypadku działania kierowane są do jakiejś szerszej grupy, w drugim do konkretnych już, wytypowanych osób. W obu przypadkach materiały przekazywane są archiwum społecznemu w formie daru bądź w formie depozytu, zależnie od dyspozycji właściciela dokumentów. Niewielka część archiwów monitoruje internetowe serwisy aukcyjne oraz lokalne antykwariaty w poszukiwaniu cennych materiałów archiwalnych, które mogłyby zakupić 9 Drugą formą pozyskiwania zasobu przez archiwa społeczne jest wywoływanie źródeł - nagrywanie bądź spisywanie relacji, robienie zdjęć. Często w jednym archiwum wykorzystywane są obie te formy pozyskiwania materiałów (poszukiwanie darczyńców i wywoływanie źródeł), nieraz wręcz jednocześnie (np. nagrywanie relacji połączone ze skanowaniem dokumentów posiadanych przez relatora).

Po przybliżeniu sposobów, stosowanych przez archiwa społeczne w celu pozyskiwania materiałów, widać, że kreują one swój zasób samodzielnie. Najpierw podejmują decyzję, czego ma ów zasób dotyczyć, tj. jaki wycinek przeszłości dokumentować. I tak dla przykładu Ośrodek KARTA gromadzi materiały na temat całego XX wieku ${ }^{10}$, Centrum Dokumentacji Czynu Niepodległościowego na temat, jak sama nazwa podpowiada, dążeń niepodległościowych Polaków ${ }^{11}$, Archiwum i Muzeum Pomorskie Armii Krajowej oraz Wojskowej Służby Polek zajmuje się gromadzeniem materiałów archiwalnych dotyczących Armii Krajowej na Pomorzu, wojskowej służby Polek, pomor-

8 Działalność Fundacji/Programy, http://www.sowiniec.com.pl/php/7_o_fundacji.php?ID3=67\&s=1\&li=0\&sort=OPS\%20DESC, tu i ówdzie (dostęp z dnia $10 \mathrm{VI}$ 2013 r.).

9 T. Filipczak, Zbiory Fundacji Centrum Dokumentacji Czynu Niepodlegtościowego w Krakowie, „Archiwista Polski” 2009, nr 3, s. 39.

10 Statut Fundacji Ośrodka KARTA, \$ 6, dostępne on-line http://www.karta.org.pl/ pdf/orginal/13291276317655.pdf (dostęp dnia 27 V 2012).

11 Aktualności/Wstęp,http://www.sowiniec.com.pl/php/7_o_fundacji.php?ID3=13\&s= 1\&li=\&sort=ID (dostęp dnia 15 V 2012 r.). 
skich konspiratorów oraz działalności konspiracyjnej po II wojnie światowej ${ }^{12}$, Archiwum Polskich Ormian zbiera materiały dotyczące dawnych Kresów Wschodnich Rzeczypospolitej, ze szczególnym uwzględnieniem dóbr kultury ormiańskiej ${ }^{13}$, Romski Instytut Historyczny dokumentuje zarówno historię, kulturę, jak i współczesne życie społeczności romskiej ${ }^{14}$, natomiast Archiwum Filmowe „Drogi do Niepodległości” przechowuje unikalne zapisy m.in. początków „Solidarności”, wydarzeń okresu stanu wojennego, obrad Okrągłego Stołu oraz początki transformacji lat dziewięćdziesiątych ${ }^{15}$. Przykłady można by mnożyć, tak wiele jest bowiem w Polsce społecznych archiwów.

Oprócz wyboru ogólnego tematu, jakiego tyczyć się będą materiały w danym archiwum, archiwa społeczne same decydują, kiedy i jakie akcje gromadzenia zasobu będą podejmować. Co więcej, mogą do tego stopnia wpływać na kształt swego zasobu, że wcale nie muszą przecież przyjmować wszystkich oferowanych im materiałów, nie muszą zgadzać się na włączanie ich do zasobu archiwum.

Jednocześnie, jak już wspomniałam, trudnią się często archiwa społeczne wywoływaniem źródeł, w tym również gromadzeniem relacji oral history. Tym samym same mogą zadecydować, kto ma zostać relatorem, a kto nie, lub jaka część relacji ma zostać włączona do archiwum. W ten właśnie sposób kreują archiwa społeczne pamięć o przeszłości np. danej zbiorowości czy danego terytorium, mogąc przy tym wpływać na kształt pamięci, a także w ogóle - czy zostanie ona zachowana.

Są jednak archiwa społeczne nie tylko depozytariuszami przeszłości (a konkretnie jakiegoś jej wycinka), ale również często kreatorami czy może przekaźnikami tożsamości danej grupy społecznej, nierzadko bowiem są archiwa tego typu mocno związane z lokalną społecznością, którą w swej działalności aktywizują.

Sądzę, że warto również zastanowić się nad tym, co jest powodem powstawania archiwów społecznych. Nie jest to bowiem zjawisko, które można by

12 Statut Fundacji Generał Elżbiety Zawackiej. Archiwum i Muzeum Pomorskie Armii Krajowej oraz Wojskowej Służby Polek, \$ 6, http://www.zawacka.pl/statut_11_04_2011.pdf (dostęp dnia 11 VII 2013 r.).

13 Statut Fundacji Kultury i Dziedzictwa Ormian Polskich, $\$ 7$, http://www.dziedzictwo.ormianie.pl/Statut (dostęp dnia 11 VII 2013 r.).

14 Romski Instytut Historyczny, http://www.stowarzyszenie.romowie.net/index. php/czytnik-artykulow/items/60.html (dostęp z dnia 10 VI 2013 r.).

15 FAF, http://www.archiwumfilmowe.org.pl/ (dostęp dnia 7 VI 2013 r.). 
było określić jako wiekowe. W Polsce właściwie możemy mówić o archiwach społecznych w większości przypadków dopiero od lat dziewięćdziesiątych ${ }^{16}$, natomiast prawdziwy boom miał miejsce po roku 2000. Odpowiedzi na pytanie o powód powstawania takich inicjatyw może być wiele ${ }^{17}$ jednak pewne wątpliwości rozwiewa lektura wspomnianego na początku Pierre’a Nory. Zwraca on uwagę na zachodzące obecnie zjawisko tzw. przyśpieszenia historii. Współcześnie rzeczą najbardziej stałą i ciągłą jest paradoksalnie zmiana - „I to zmiana coraz szybsza, przyśpieszone zapadanie wszystkiego w przeszłość, oddalającą się coraz szybciej ${ }^{18 ”}$ ". To właśnie z powodu coraz szybszych i coraz dalej idących zmian przyszłość jest bardziej niepewna, niż była kiedykolwiek przedtem. Ponadto teraźniejszość dysponuje takimi technicznymi środkami przeznaczonymi do zachowywania śladów przeszłości, jakimi nie dysponowano nigdy wcześniej; największe znaczenie ma tu rzecz jasna zapis cyfrowy. Dlatego też na współczesnego człowieka nałożono „obowiązek pamiętania”, zwłaszcza, że wspomniane już „przyśpieszenie historii” powoduje oddalenie się przeszłości, która jawi się już tylko za pośrednictwem pozostawionych śladów. Pierre Nora widzi bardzo istotny skutek zjawiska „przyśpieszenia historii”, jakim jest gromadne powstawanie m.in. instytucji pamięci, w tym archiwów ${ }^{19}$.

Ponadto francuski historyk wskazuje również na zjawisko, które nazywa „demokratyzacją" historii. Polega ona na emancypacji różnych grup, zwłaszcza narodów, ale także jednostek, co wiąże się z emancypacją różnych pamięci mniejszości, „dla których odzyskanie własnej przeszłości stanowi integralną część afirmacji ich tożsamości ${ }^{20 ”}$. W związku z tym porusza Pierre Nora zagadnienie dekolonizacji, wymieniając trzy jej rodzaje. Pierwszy z nich to dekolonizacja światowa, która doprowadziła do stworzenia lub odzyskania pamięci oraz świadomości społeczeństw uciskanych wcześniej przez ko-

16 Ciekawym przykładem archiwum społecznego powstałego dużo wcześniej jest Polskie Archiwum Wojenne, powołane do życia w 1915 r., a zajmujące się zbieraniem materiałów związanych z udziałem Polaków w I wojnie światowej oraz ze sprawą polską; patrz: H. Robótka, B. Ryszewski, A. Tomczak, Archiwistyka, Warszawa 1989, s. 327; Polskie Archiwum Wojenne, http:/www.wycinki.olejow.pl/?p=7361\#more-7361 (dostęp z dnia 17 VII 2013 r.).

17 Patrz: M. Wiśniewska, Postmodernizm a archiwa spoteczne, „Archiwista Polski” 2013, nr 2, s. 25-29.

18 P. Nora, Czas pamięci, przekł. W. Dłuski, „Res Publica Nowa”, Lipiec 2001, s. 39.

19 Tamże, s. 40.

20 Tamże, s. 41. 
lonializm. Drugi typ dekolonizacji to dekolonizacja wewnętrzna mniejszości (np. seksualnych czy religijnych), spotykana w klasycznych społeczeństwach zachodnich. Przez „proklamowanie swej pamięci” mniejszości mogą z jednej strony zdobyć uznanie pozostałej części społeczeństwa (większości), a z drugiej strony - zaznaczyć swą odrębność wobec niej. Trzeci typ dekolonizacji to zjawisko spotykane w państwach dotkniętych niegdyś dwudziestowiecznymi totalitaryzmami i dyktaturami, tj. w Rosji, krajach Europy Środkowo-Wschodniej i Bałkanów, a także Ameryki Łacińskiej i Afryki. Ten rodzaj dekolonizacji nazywa Nora dekolonizacją ideologiczną, a związana jest ona z odzyskiwaniem przez wyzwolone narody dawnych tradycji i dawnej pamięci, zakazanych, zniszczonych lub zmanipulowanych przez reżimy, oferujące jedynie jedną właściwą, oficjalną pamięć państwową ${ }^{21}$.

$\mathrm{Na}$ gruncie polskim przykładem powstania archiwum społecznego w wyniku dekolonizacji wewnętrznej będą chociażby Archiwum Polskich Ormian, Romski Instytut Historyczny czy Stowarzyszenie Ola Archiwum - Ogólnopolskie Feministyczne Archiwum Lesbijskie. Natomiast wynikiem dekolonizacji ideologicznej będzie np. powstanie Ośrodka KARTA, a zwłaszcza jego działania jeszcze przed sformalizowaniem swej działalności, tj. przed rokiem 1990. Wtedy to współpracownicy „Karty” zbierali materiały na temat zakazanej przez ówczesne władze tzw. historii „wschodniej” - głównie relacje Polaków represjonowanych w ZSRR ${ }^{22}$, ale także materiały dotyczące działalności opozycji antykomunistycznej w PRL ${ }^{23}$.

Podsumowując, wszystkie archiwa, bez względu na to, jakiego są one typu, są miejscami pamięci jako instytucje, a jednocześnie gromadzą miejsca pamięci, to jest dokumenty (o ile przyjmie się najszersze rozumienie terminu „miejsca pamięci”). W temacie jednak kreowania pamięci ważne wydaje mi się podkreślenie roli archiwów prywatnych oraz archiwów społecznych, które odróżniają się od innych typów archiwów dwoma przymiotami: dobrowolnością i dowolnością - dobrowolnością gromadzenia dokumentów, podjęcia się w ogóle tego zadania oraz dowolnością w ich wyborze, bowiem nie są one związane niemal żadnymi nakazami pochodzącymi np. z przepisów prawnych, jak jest to w wypadku archiwów państwowych, kościelnych czy bie-

21 Tamże.

22 Z. Gluza, KARTA - sposób na historię, „Karta” 50 (2006), s. 116; Informacje ogólne, http://www.karta.org.pl/Informacje_ogolne/73 (dostęp dnia 17 VII 2013 r.).

23 Archiwum Opozycji, http://karta.org.pl/Archiwa_i_bazy_danych/Archiwum_ Opozycji/50 (dostęp dnia 17 VII 2013 r.). 
żących. Tym samym w archiwach prywatnych i społecznych widać bardziej niż w innych „rękę człowieka” - są samoświadectwem danej osoby, rodziny czy grupy społecznej - same tworzą pamięć o sobie oraz umożliwiają, właśnie dzięki zachowywaniu miejsc pamięci, jej podtrzymanie.

\section{Bibliografia}

Chorążyczewski W., Archiwa i pamięć. Z dziejów polskich archiwów, [w:] „Archiwa - Kancelarie - Zbiory”, t. 1, pod red. W. Chorążyczewskiego, R. Degena, K. Syty, Toruń 2005.

Filipczak T., Zbiory Fundacji Centrum Dokumentacji Czynu Niepodlegtościowego w Krakowie, „Archiwista Polski” 2009, nr 3.

Gluza Z., KARTA - sposób na historię, „Karta” 2006, nr 50.

Nora P., Between Memory and History. Les lieux de mémoire, „Representations”, Spring 1989, no. 26.

Nora P., Czas pamięci, przekł. W. Dłuski, „Res Publica Nowa”, lipiec 2001.

Pomian K., Pamięć podzielona: miejsca pamięci w Europie jako zjawisko polityczne i kulturowe, http://enrs.eu/images/teksty\%20pdf\%20pol/Pomian_pamiec.pdf (dostęp $5 \mathrm{~V}$ 2013 r.).

Ricoeur P., Pamięć, historia, zapomnienie, przekł. J. Margański, Kraków 2007.

Robótka H., Ryszewski B., Tomczak A., Archiwistyka, Warszawa 1989.

Szpociński A., Miejsca pamięci (lieux de mémoire), „Teksty Drugie” [„Second Texts”] 2008, nr 4.

Vorbek-Lettow M., Skarbnica pamięci: pamiętnik lekarza króla Wtadystawa IV, oprac. E. Galos i F. Mincer, pod red. nauk. W. Czaplińskiego, Wrocław 2006.

Wiśniewska M., Postmodernizm a archiwa spoteczne, „Archiwista Polski”, 2013, nr 2.

\section{Sum mary}

\section{Archives as a Memorial}

In this article the Author proves archive to be a memorial, as the term is understood by the thesis presented by Pierre Nora.

In line with this thesis, it is the author's belief, that as a place that stores archival materials, every archive serves as a memorial, since it allows to look into the information and enter the past which is kept in them. Every type of archives is a depositary of the past.

Moreover, the author claims archive to be a place where memory is created and not only preserved. The author proposes to divide archives into two groups, with 


\section{Magdalena WiśniewsKa}

state, church and current records in one and social and private archives in the other. At the same time, She emphasizes two properties that are distinctive of the second group of archives, as opposed to the first one. They are: VOLITION (the act of gathering archival funds on one's own initiative) and ARBITRARINESS (mostly as to the choice of materials gathered).

The author draws our attention to the fact that a private archive may serve as a means to creating one's persona or creating a rememberance of one's lineage or family; it is also the testimony of its owner - as it is him or her who shapes the archive, and, at the same time, decides on the way future generations will remember him or her. On the other hand, social data archives create the history of a given community or territory, at the same time shaping it or even allowing it to be preserved in any way at all. In the case of social archives, the author draws attention to the reasons for the formation of archives referring to "acceleration of history" and "democratisation of history". 